\title{
Spraying opened sugar beet pulp silage with oregano essential oil helps to sustain quality and stability
}

\author{
H. Çayıroğlu ${ }^{1 \#}$, G. Filik ${ }^{2}$, İ. Coşkun ${ }^{1}$, A. Gül Filik², H. Çayan ${ }^{1}$ \& A. Şahin ${ }^{1}$ \\ ${ }^{1}$ Department of Animal Science, Faculty of Agriculture, Kırşehir Ahi Evran University, 40100 Kırşehir, Turkey \\ ${ }^{2}$ Department of Agricultural Biotechnology, Faculty of Agriculture, Kırşehir Ahi Evran University, 40100 Kırşehir, Turkey
}

(Received 12 September 2019; Accepted 22 November 2019; First published online 16 February 2020)
Copyright resides with the authors in terms of the Creative Commons Attribution 4.0 South African License.
See: http://creativecommons.org/licenses/by/4.0/za
Condition of use: The user may copy, distribute, transmit and adapt the work, but must recognize the authors and the South African Journal of Animal Science.

\begin{abstract}
This study was conducted to determine the effects of spraying oregano essential oil (OEO) onto sugar beet pulp silage (SBPS) on silage quality and aerobic stability after opening. A factorial experiment with three replicates of three treatments and four time periods was conducted using laboratory-type plastic silos. The treatments were an untreated control, silage sprayed with $10 \mathrm{ml} / 75 \mathrm{~cm}^{2}$ OEO, and silage sprayed with 20 $\mathrm{ml} / 75 \mathrm{~cm}^{2}$ OEO. The silages were sampled at $0,72,120$, and 168 hours after spraying. Temperature, $\mathrm{L}^{*}, \mathrm{a}^{*}$, and $\mathrm{b}^{*}$ colour values, $\mathrm{pH}$, water-soluble carbohydrates, crude nutrient contents, Fleig score, metabolizable energy (ME) value, lactic acid bacteria (LAB), total live bacteria (TLB), yeast, and mould formation were assessed. Spraying OEO onto SBPS did not affect $L^{*}, a^{*}$, and $b^{*}$ values, $\mathrm{pH}$, water-soluble carbohydrates, and Fleig score values, but decreased temperature. Spraying OEO onto the silage increased organic matter, ether extract, acid detergent fibre, neutral detergent fibre and acid detergent lignin contents without affecting crude protein, crude fibre, nitrogen free extract, and ME contents. Irrespective of treatment, crude protein, ether extract, acid detergent fibre, acid detergent lignin, nitrogen free extract, Fleig score, and ME contents of silages increased with time after spraying. The OEO spraying reduced LAB, TLB, and yeast contents in silages. In conclusion, OEO spraying onto opened SBPS reduced LAB, TLB, and yeast formation and stopped mould growth up to 72 hours without affecting their nutritional properties, suggesting that OEO could be used to ensure the stability of SBPS.
\end{abstract}

Keywords: aerobic stability, mould growth, silage microbiology, nutrients, feeding management

${ }^{\#}$ Corresponding author: hayrettincayiroglu@ahievran.edu.tr

\section{Introduction}

Sugar beet pulp (SBP), which is one of the sugar industry's by-products, has been widely used in ruminant rations because it is rich in pectin, contains highly digestible fibre in its structure, and is inexpensive. Moreover, it has certain advantages over cereal grains since it is not expensive and does not cause metabolic disorders such as acidosis in ruminant animals (Aldemir et al., 2019). Sugar beet pulp contains $10.00-15.00 \%$ crude protein (CP), $20.00-25.00 \%$ crude fibre (CF), $0.60 \%$ ether extract (EE), and $2.51-4.40 \%$ ash on dry matter basis (Zheng et al., 2011; Zheng et al., 2013; Naderi et al., 2016; Gerlach et al., 2017; Sargın \& Denek, 2017; Aldemir et al., 2019). It also contains $2.67 \mathrm{Mcal} / \mathrm{kg}$ DM metabolizable energy and $1.61 \mathrm{Mcal} / \mathrm{kg} \mathrm{DM}$ net energy lactation (Ülger et al., 2018). Sugar beet pulp is a good silage material for ruminant nutrition and is used mainly as silage in countries where is farmed. However, nutritional loses happen during storage and feeding. After it is opened, SBP silage (SBPS) may cause nutrient losses of $40-60 \%$ according to time (Konca et al., 2005; Hellwing et al., 2017; Borreani et al., 2018; Ferrero et al., 2019). One of the most important issues in silage production is aerobic stability. When silage is opened or served to the animals, atmospheric oxygen enters the silo, causing undesirable microorganisms to proliferate, and silage quality to deteriorate (Kung, 2001; Filya, 2004; Koç et al., 2010; Çayıroğlu et al., 2016; Kızılşimsek et al., 2016; Borreani et al., 2018; Kung Jr et al., 2018; Özelçam \& Dașıkan, 2017; Silva et al., 2018). These deteriorated silages must not be offered to the animals. If consumed, the moulds may produce lethal mycotoxins and, consequently, pass from animal products to human beings to cause several illnesses (Koç et al., 2010; Kızılşimsek et al., 2016; Kaya, 2017; Ferrero et al., 2019). 
Various chemically and biologically derived additives such as essential oils can be used to improve silage quality and suppress the proliferation of microorganisms that cause deterioration from the beginning of the fermentation (Kung, 2001; Filya et al., 2004; Koç et al., 2010; Chaves et al., 2012; Soycan Önenç et al., 2015; Çayıroğlu et al., 2016; Soycan Önenç et al., 2017; Muck et al., 2018; Mutavhatsindi et al., 2018; Silva et al., 2018). Essential oils have microbial contamination-retarding and deterioration-reducing effects against a wide range of microorganisms (Chaves et al., 2012; Özelçam \& Dașıkan, 2017; Turan \& Önenç Soycan, 2018). Although these products have been used widely in animal nutrition because of these effects, their usage in silage fermentation and stability has been fairly new (Chaves et al., 2012; Soycan Önenç et al., 2015; Soycan Önenç et al., 2017).

Many anti-microbial essential oils prevent the proliferation bacteria in silage, of which oregano essential oil (OEO) is one. It contains $59.03 \%$ carvacrol and $12.04 \%$ thymol (Soycan Önenç et al., 2017). Carvacrol has flavouring and appetizing traits, and it also destroys pathogenic microorganisms (Kung, 2001; Çayıroğlu et al., 2016; Özelçam \& Dașıkan, 2017).

Özelçam and Dașıkan (2017) did a study to determine the effects on aerobic stability, pH and visual mould of the addition of carvacrol to maize silage. They found that it did not affect the $\mathrm{DM}$ and $\mathrm{pH}$ values, but decreased the amount of $\mathrm{CO}_{2}$, improved aerobic stability, and reduced visual mildew. Soycan Önenç et al. (2017) reported that the organic acid in peas showed a high level of antimicrobial activity in silages, inhibiting the growth of yeast and mould, and improving the aerobic stability of cinnamon essential oil addition. In earlier studies, OEO and other essential oils were used at the beginning of the fermentation. However, there has been no study on the inclusion of the OEO after opening silage. This study has questioned whether aerobic stability can be improved via suppressing undesirable microorganisms by spraying OEO after SBPS has been opened. Therefore, the aim of this study was to determine the effects with time on aerobic stability, change of nutritional composition and microorganism populations with spraying OEO onto SBPS.

\section{Materials and Methods}

Sugar beet pulp that was used as silage material in this study was obtained from Kırşehir Sugar Factory. The OEO was purchased from a private company (BIOMESTICS Bioagrotechnology Research and Development Activities Company, Adana, Turkey). The chemically active compounds of the OEO (Table 1), which was extracted from Origanum minutiflorum, are based on analysis conducted by BIOMESTICS. The effective compound of oregano oil in Table 1 is carvacrol, the antimicrobial effects of which are well known (Kung, 2001; Özelçam \& Dașıkan, 2017; Soycan Önenç et al., 2017).

The study had a $3 \times 4$ factorial experimental design with three replicates. The treatments were an untreated control (C), silage sprayed with $10 \mathrm{ml} / 75 \mathrm{~cm}^{2}$ OEO (T10), and silage sprayed with $20 \mathrm{ml} / 75 \mathrm{~cm}^{2}$ OEO (T20). The OEO was sprayed on the surface of the opened silage.

Experimental SBP materials were obtained from Kırşehir Sugar Factory in Turkey in $25 \mathrm{~kg}$ vacuumsealed plastic bags. They were brought to Kırşehir Ahi Evran University, Faculty of Agriculture, Feed Biotechnology Laboratory for chemical and microbiological analyses. The SBP was filled into $36 \times 2 \mathrm{~kg}$ laboratory-type plastic silo jars. The jars were closed and kept under laboratory conditions to ferment for 60 days, after which time the silo jars were opened. Samples were taken from the top five $\mathrm{cm}$ from the silage surface for chemical and microbiological analyses. Then, the treatments were applied by spraying OEO into the mouths of the jars to cover the surface area $\left(75 \mathrm{~cm}^{2}\right.$ area). The OEO spray was not applied to the control material. The jars were subsequently kept at ambient temperature $\left(21 \pm 2{ }^{\circ} \mathrm{C}\right)$ without closing until the time of sampling. Aerobic stability monitoring was performed at 72 (3rd day), 120 (5th day), and 168 hours (7th day) in each silage. Lactic acid bacteria (LAB), total live bacteria (TLB), and yeast and mould contents were determined together with temperature, $\mathrm{pH}$, water soluble carbohydrates (WSC), and $\mathrm{L}^{*}, \mathrm{a}^{*}$, and $\mathrm{b}^{*}$ values in silage samples.

The silage surface colour of the samples was determined with a Konica Minolta CR 410 portable Chroma-meter. These data were recorded on the following scales: $\left(L^{*}\right)$ brightness (0: black, 100: white), $\left(a^{*}\right)$ from red to green $\left(+a^{*}\right.$ : red; $-a^{*}$ : green), and $\left(b^{*}\right)$ from yellow to blue $\left(+b^{*}\right.$ : yellow, $-b^{*}$ : blue). Four measurements were taken from each sample and the colour values were averaged.

The $\mathrm{pH}$ value was determined with Testo $206 \mathrm{pH}$ meter. The WSC value (Brix degree $0-25^{\circ}$ ) measured with a refractometer. Organic matter (OM), dry matter (DM), CP, ether extract (EE), nitrogen free extract (NFE), ash contents (AOAC, 1998), acid detergent fibre (ADF), neutral detergent fibre (NDF), acid detergent lignin (ADL) and CF contents (Van Soest et al., 1991) of silages were determined. The Fleig score (FS), which contained the $\mathrm{DM}$ and $\mathrm{pH}$ values of the silages was estimated from this formula, which was proposed by Kılıç (1986).

$$
\mathrm{FS}=220+(2 \times \mathrm{DM} \%-15)-40 \times \mathrm{pH}
$$


Table 1 Active compounds of oregano oil used in the experiment

\begin{tabular}{lr}
\hline Compound & $\%$ \\
\hline a-Pinene & 0.17 \\
ס-3-Carene & 0.56 \\
Camphene & 0.13 \\
Sabinene & 0.05 \\
$\beta$-Myrcene & 0.40 \\
$\alpha$-Phellandrene & 0.07 \\
a-Humulene & 0.54 \\
p-Cymene & 10.78 \\
$\beta$-Phellandrene & 0.10 \\
1.8-Cineol & 0.11 \\
Y-Terpinen & 1.35 \\
$\alpha$-Terpinolene & 0.04 \\
Linalool & 0.72 \\
Trans-Sabinene hydrate & 0.30 \\
Carvacrol & 84.13 \\
Trans-Caryophellandrene & 0.27 \\
Aromadendrene & 0.03 \\
$\alpha$-Bisabolene & 0.25 \\
Total & 100.00 \\
\hline
\end{tabular}

The metabolizable energy (ME) of silage was calculated by using the ME formula that was developed for the Turkish Standards Institute (TSE) TSE 9610 for ruminant animals (TSE, 1991):

$$
\mathrm{ME}=3260+0.455(\mathrm{CP})-4.037(\mathrm{CF})+3.517(\mathrm{EE})
$$

where, the units of measure for ME, CP, CF, and EE are $\mathrm{g} / \mathrm{kg} \mathrm{OM}$.

Ten grams of silage contents per sample was weighed out, dissolved in $90 \mathrm{~mL}$ of distilled water, and vortexed for $5 \mathrm{~min}$. Each silage homogenate was diluted exactly tenfold $(10 \mathrm{w} / \mathrm{v})$ from $10^{1}$ to $10^{7}$. Diluted samples $(0.1 \mathrm{~mL})$ were inoculated into selective agar for further bacterial enumeration. Plate count agar (MERCK, Darmstadt, Germany, 105463) was used to enumerate TLB at $30^{\circ} \mathrm{C}$ for a 3-day incubation period. MRS agar (MERCK, Darmstadt, Germany, 110660) was used to enumerate LAB at $37{ }^{\circ} \mathrm{C}$ for a 3-day incubation period, and malt extract agar (MERCK, Darmstadt, Germany, 105398) was used to enumerate yeast and moulds at $30^{\circ} \mathrm{C}$ for a 3-day incubation period. Bacterial colonies were counted by determining the average number of live bacteria per gram silage content. $L A B$, yeast and mould counts of the samples were converted into logarithmic colony forming units $\left(\mathrm{cfu} \mathrm{g}^{-1}\right)$.

Data were subjected to analysis of variance using the general linear model's procedure of SPSS (version 17.00, SPSS Inc., Chicago, Illinois, USA). Means were compared between experimental silages by Duncan's Multiple Range Test.

\section{Results and Discussion}

In the current study, the temperature in silages was between 24.77 and $25.14{ }^{\circ} \mathrm{C}$ at the first opening time (Table 2). It was decreased by both treatment and time $(P<0,000)$, that is, to $21.97^{\circ} \mathrm{C}$ at 168 hours in T10 silage. The treatment and time interaction effect was not important (Table 2). Temperatures of silages decreased throughout time and treatment $(P<0.001)$. Effects of the treatment by time interaction were not important.

The OEO spraying did not affect the $\mathrm{L}^{*}, \mathrm{a}^{*}$ and $\mathrm{b}^{*}$ values of the silages $(P>0.05)$, but these values decreased with time $(P<0.000)$. Similarly, Toruk et al. (2010) reported that microbial and enzyme supplementation on the silage surface affected colour stability six days after opening packaged silages. In 
terms of $L^{*}$ and $b^{*}$ values, the treatment and time interaction tended to be important $(P=0.058) . L^{*}$, $a^{*}$ and $b^{*}$ values decreased throughout time, and treatment and time interaction effect was important $(P<0.001)$. While the lowest $L^{*}$ value in the silage was obtained at 168 hours (36.39) in T20 silage, the highest $L^{*}$ value was obtained at 0 hours (51.73) in T10 silage (Table 2). The increase in $\mathrm{L}^{*}, \mathrm{a}^{*}$, and $\mathrm{b}^{*}$ values in the early control group may have resulted from sample error because in the OEO-supplemented groups decreases in $L^{*}, a^{*}$, and $b^{*}$ values were linear.

Microbiota populations of the silages are given in Table 3. Spraying OEO onto the silages dramatically decreased LAB, TLB, and yeast count after opening silage at 72 hours, but the mould count was not changed. Thus, OEO showed a strong initial antimicrobial effect on the LAB, TLB, and yeast in silage. Since the volatile components in OEO with time evaporated into the atmosphere, its effective compounds were diluted in the silage liquid with time and its suppressive effect on the bacteria slowed down. Therefore, LAB was completely inhibited by OEO and recovered at 72 hours after application. Spraying OEO after opening the silage stopped yeast growth completely in the first few days, but it started to develop again in later periods. OEO spray tended to decrease the number of moulds compared with control but without statistical significance. The decrease in yeast and mould numbers in the treatment groups may be because the active components in OEO may suppress aerobic bacteria, yeast and mould growth.

The $\mathrm{pH}$ of the silages was not affected by the treatment (Table 4). However, time had an important effect $(P<0.001)$ with all of the silages increasing in $\mathrm{pH}$ with the passage of time since opening reflecting a progressive decrease in acidity. In this study, the $\mathrm{pH}$ value of silages increased from 3.55 to 4.41 . A pH between 3.5 and 5.0 is necessary for good fermentation (Kung Jr et al., 2018). Here, the OEO spray did not affect pH. Similarly, Chaves et al. (2012) did not find any effects of cinnamon leaf, partridgeberry and sweet orange essential oil treatments on the $\mathrm{pH}$ of barley silage. Özelçam and Daşıkan (2017) did not find any effect of adding carvacrol to corn silage on its $\mathrm{pH}$ either. This might be owing to the absence of carbohydrates in OEO.

Water-soluble carbohydrate (WSC) contents of silages ranged from 11.0 to $12.5 \mathrm{~g} / \mathrm{kg}$ (Table 4). The WSC content was similar across all treatments and time points $(P>0.05)$. WSC and other nitrogen-free nutrients in the silage material may provide a nutritional substrate for the microorganisms in the silage (Çelebi, 2010) and by suppressing these communities the carbohydrate fractions were maintained.

Oregano essential oil treatment increased the OM content of silages $(P<0.05)$ (Table 4). While the highest OM value (94.85\%) was obtained at 168 hours in T10 silage, the lowest value (94.36\%) was obtained at 72 hours in control silage.

Oregano essential oil treatment did not affect the CP content of silages, whereas CP increased significantly over time. Although the time-dependent changes in the CP content of control and T20 silages were not significant, the CP content of the T10 silage increased linearly from $5.54 \%$ on first opening to $6.09 \%$ at 168 hours after opening. Oregano essential oil treatment increased EE contents in silages compared with $\mathrm{C}$ silage $(P<0.001)$. The effect of time and OEO on silages was important in the EE content (Table 4). The significant increases in the EE contents by treated silages may be due to the obvious consequence of having provided extra oil to these silages.

Oregano essential oil treatment did not change CF contents. However, ADF, NDF, and ADL contents were affected by treatments (Table 4). Application of OEO at $20 \mathrm{ml}$ per $75 \mathrm{~cm}^{2}$ of opened silage surface increased ADF content and decreased NDF content after 168 hours. These results suggested that OEO spray or supplementation did not affect the digestible fibre content of silages in T10, but OEO spray increased the ADF and decreased the NDF content of silages in T20. This could be attributed to the breakdown of plant cell walls in the silage material by OEO (Çelebi, 2010). It might be that high dosages of OEO decrease the digestibility of silage. However, digestion trials were not conducted in the present study. The digestibility of silages that are sprayed with high dosages of essential oils should be investigated.

The ash contents of the silages were decreased by treatment $(P<0.05)$, but this did not continue with time $(P>0.05)$ (Table 3). The content of NFE in silages was not affected by treatments, whereas there were linear decreases in NFE content with time in the T20 group $(P<0.05)$ (Table 4).

Fleig scores of experimental silages are given in Table 3. According to Table 3, OEO spray and OEO spray and time interaction effect was not important. Time was an important effect on Fleig score of silages. Fleig scores for silages that are between 80 and 100 are considered very good; 61 to 80 are good; 41 to 60 are medium; 21 to 40 are low quality; between 0 and 20 are considered reflective of poor-quality silage (Kılıç, 1986). Spraying OEO affected Fleig scores with time $(P<0.000)$. While the highest Fleig score $(99.98)$ was obtained at 72 hours in T20 silage, the lowest Fleig score (63.36) was obtained at 168 hours in T10 silage. These scores in T10 and T20 silages exceeded those of C. Thus, the OEO spray may have contributed to the preservation of the silages. 
Table 2 Effects of treatment and time on $\mathrm{pH}$, temperature, and colour values of the control and silages treated with oregano essential oil

\begin{tabular}{|c|c|c|c|c|c|c|c|c|c|c|c|c|c|c|c|c|}
\hline \multirow{3}{*}{ Time $(\mathrm{H})$} & \multicolumn{12}{|c|}{ Treatments $(\mathrm{T})$} & \multirow{3}{*}{ SEM } & \multirow{2}{*}{\multicolumn{3}{|c|}{$P$-values }} \\
\hline & \multicolumn{4}{|c|}{ Control } & \multicolumn{4}{|c|}{$\mathrm{T} 10$} & \multicolumn{4}{|c|}{ T20 } & & & & \\
\hline & 0 & 72 & 120 & 168 & 0 & 72 & 120 & 168 & 0 & 72 & 120 & 168 & & $\mathrm{~T}$ & $\mathrm{H}$ & $\mathrm{T}^{*} \mathrm{H}$ \\
\hline Temperature, ${ }^{\circ} \mathrm{C}$ & $25.14^{\mathrm{a}}$ & $24.27^{c}$ & $23.83^{d}$ & $22.17^{\mathrm{e}}$ & $24.77^{b}$ & $24.13^{c}$ & $23.70^{d}$ & $21.97^{\dagger}$ & $24.80^{b}$ & $24.11^{c}$ & $23.67^{d}$ & $22.00^{\text {ef }}$ & 0.179 & 0.000 & 0.000 & 0.456 \\
\hline$L^{*}$ & $48.57^{\mathrm{abc}}$ & $38.20^{\mathrm{e}}$ & $45.46^{\mathrm{bcd}}$ & $36.81^{e}$ & $51.73^{\mathrm{a}}$ & $43.60^{\mathrm{cd}}$ & $43.51^{c d}$ & $36.74^{\mathrm{e}}$ & $50.22^{\mathrm{ab}}$ & $50.57^{\mathrm{ab}}$ & $40.88^{\text {de }}$ & $36.39^{e}$ & 1.014 & 0.149 & 0.000 & 0.002 \\
\hline$a^{*}$ & $4.26^{\mathrm{abc}}$ & $3.40^{\text {de }}$ & $4.59^{a}$ & $3.43^{\text {cde }}$ & $4.56^{\mathrm{ab}}$ & $3.91^{\mathrm{abcd}}$ & $4.41^{\mathrm{ab}}$ & $3.05^{\mathrm{e}}$ & $4.53^{\mathrm{ab}}$ & $4.24^{\mathrm{abc}}$ & $3.73^{\text {bcde }}$ & $3.55^{\text {cde }}$ & 0.105 & 0.963 & 0.000 & 0.058 \\
\hline$b^{*}$ & $15.15^{\mathrm{ab}}$ & $9.73^{\text {ef }}$ & $11.92^{\mathrm{cd}}$ & $9.31^{\text {ef }}$ & $16.40^{\mathrm{a}}$ & $11.06^{\mathrm{de}}$ & $11.94^{\mathrm{cd}}$ & $9.06^{f}$ & $15.40^{\mathrm{ab}}$ & $13.73^{\mathrm{bc}}$ & $10.79^{\text {def }}$ & $9.55^{\mathrm{ef}}$ & 0.441 & 0.145 & 0.000 & 0.006 \\
\hline
\end{tabular}

${ }^{\mathrm{a}-\mathrm{t}}$ Within rows, means with a common superscript are not significantly different at $P \leq 0.05$

$L^{*}$ : brightness (0: black, 100: white); $a^{*}$ : from red to green $\left(+a^{*}:\right.$ red; $-a^{*}$ : green); $b^{*}$ : from yellow to blue (+b $b^{*}$ : yellow, $-b^{*}$ : blue)

T10: silage sprayed with $10 \mathrm{ml}$ oregano essential oil per $75 \mathrm{~cm}^{2}$ opened silage surface; T20: silage sprayed with $20 \mathrm{ml}$ oregano essential oil per $75 \mathrm{~cm}$ opened silage

surface

Table 3 Effects of treatment and time on microorganism populations of the control and oregano essential oil treated sugar beet pulp silages reported as $\log _{10} \mathrm{cfu} / \mathrm{g} \mathrm{DM}$

\begin{tabular}{|c|c|c|c|c|c|c|c|c|c|c|c|c|c|c|c|c|}
\hline \multirow{3}{*}{ Time $(\mathrm{H})$} & \multicolumn{12}{|c|}{ Treatments $(\mathrm{T})$} & \multirow{3}{*}{ SEM } & \multirow{2}{*}{\multicolumn{3}{|c|}{$P$-values }} \\
\hline & \multicolumn{4}{|c|}{ Control } & \multicolumn{4}{|c|}{$\mathrm{T} 10$} & \multicolumn{4}{|c|}{ T20 } & & & & \\
\hline & 0 & 72 & 120 & 168 & 0 & 72 & 120 & 168 & 0 & 72 & 120 & 168 & & $\mathrm{~T}$ & $\mathrm{H}$ & $\mathrm{T}^{*} \mathrm{H}$ \\
\hline LAB & $7.08^{\mathrm{ab}}$ & $7.74^{\mathrm{a}}$ & $7.96^{\mathrm{a}}$ & $8.97^{\mathrm{a}}$ & $7.10^{\mathrm{ab}}$ & $0^{d}$ & $1.04^{d}$ & $5.33^{b}$ & $6.97^{\mathrm{ab}}$ & $0^{d}$ & $1.57^{\mathrm{cd}}$ & $3.14^{c}$ & 0.420 & 0.001 & 0.001 & 0.001 \\
\hline TLB & $6.75^{\mathrm{abcd}}$ & $7.36^{\mathrm{abc}}$ & $7.70^{\mathrm{ab}}$ & $8.5^{\mathrm{a}}$ & $4.41^{\mathrm{bcd}}$ & $3.65^{d}$ & $4.15^{\mathrm{cd}}$ & $5.73^{\mathrm{abcd}}$ & $5.18^{\mathrm{bcd}}$ & $4.24^{\mathrm{cd}}$ & $4.03^{\mathrm{cd}}$ & $6.36^{\mathrm{abcd}}$ & 0.330 & 0.001 & 0.140 & 0.970 \\
\hline Yeast & $5.46^{\mathrm{abc}}$ & $4.83^{b c}$ & $6.88^{\mathrm{ab}}$ & $8.02^{\mathrm{a}}$ & $3.05^{\mathrm{cd}}$ & $0.87^{\mathrm{de}}$ & $0^{\mathrm{e}}$ & $5.95^{\mathrm{ab}}$ & $4.96^{\mathrm{bc}}$ & $0^{\mathrm{e}}$ & $2.07^{\mathrm{de}}$ & $4.90^{\mathrm{bc}}$ & 0.380 & 0.001 & 0.001 & 0.020 \\
\hline Mould & 1.93 & 1.20 & 2.62 & 4.11 & 1.47 & 1.58 & 1.91 & 1.26 & 0.90 & 1.46 & 2.24 & 2.85 & 0.320 & 0.530 & 0.420 & 0.880 \\
\hline
\end{tabular}

${ }^{\mathrm{a}-\mathrm{e}}$ Within rows, means with a common superscript are not significantly different at $P \leq 0.05$

T10: silage sprayed with $10 \mathrm{ml}$ oregano essential oil per $75 \mathrm{~cm}^{2}$ opened silage surface; T20: silage sprayed with $20 \mathrm{ml}$ oregano essential oil per $75 \mathrm{~cm}{ }^{2}$ opened silage surface; LAB: lactic acid bacteria, TLB: total live bacteria. 
Table 4 Effects of treatment and time on nutritional value of the control and oregano essential oil treated sugar beet pulp silages

\begin{tabular}{|c|c|c|c|c|c|c|c|c|c|c|c|c|c|c|c|c|}
\hline \multirow{3}{*}{ Time $(H)$} & \multicolumn{12}{|c|}{ Treatments $(T)$} & \multirow{3}{*}{ SEM } & \multirow{2}{*}{\multicolumn{3}{|c|}{$P$ Values }} \\
\hline & \multicolumn{4}{|c|}{ C } & \multicolumn{4}{|c|}{$\mathrm{T} 10$} & \multicolumn{4}{|c|}{ T20 } & & & & \\
\hline & 0 & 72 & 120 & 168 & 0 & 72 & 120 & 168 & 0 & 72 & 120 & 168 & & $\mathrm{~T}$ & $\mathrm{H}$ & $\mathrm{T}^{*} \mathrm{H}$ \\
\hline $\mathrm{pH}$ & $3.70^{\text {de }}$ & $3.68^{\text {de }}$ & $3.91^{\mathrm{cd}}$ & $4.4^{\mathrm{a}}$ & $3.54^{\mathrm{e}}$ & $3.66^{\mathrm{e}}$ & $4.14^{\mathrm{bc}}$ & $4.41^{\mathrm{a}}$ & $3.63^{\mathrm{e}}$ & $3.55^{\mathrm{e}}$ & $4.06^{\mathrm{bc}}$ & $4.27^{\mathrm{ab}}$ & 0.056 & 0.50 & 0.00 & 0.19 \\
\hline WSC ( ${ }^{\circ}$ Brix) & 11.67 & 11.33 & 11.33 & 11.17 & 11.67 & 11.67 & 11.33 & 11.50 & 12.00 & 11.00 & 11.83 & 12.50 & 0.100 & 0.14 & 0.32 & 0.18 \\
\hline OM, g / 100 g DM & $94.65^{\mathrm{ab}}$ & $94.36^{\mathrm{b}}$ & $94.53^{\mathrm{ab}}$ & $94.66^{\mathrm{ab}}$ & $94.79^{a b}$ & $94.80^{\mathrm{ab}}$ & $94.79^{a b}$ & $94.85^{\mathrm{a}}$ & $94.65^{\mathrm{ab}}$ & $94.83^{\mathrm{a}}$ & $94.70^{\mathrm{ab}}$ & $94.79^{\mathrm{ab}}$ & 0.040 & 0.04 & 0.78 & 0.77 \\
\hline $\mathrm{CP}, \mathrm{g} / 100 \mathrm{~g} \mathrm{DM}$ & $5.54^{c}$ & $5.85^{\mathrm{abc}}$ & $5.68^{\mathrm{bc}}$ & $5.81^{a b c}$ & $5.58^{c}$ & $5.69^{b c}$ & $6.01^{\mathrm{ab}}$ & $6.09^{\mathrm{a}}$ & $5.56^{c}$ & $5.74^{\mathrm{bc}}$ & $5.68^{\mathrm{bc}}$ & $5.84^{\mathrm{abc}}$ & 0.037 & 0.12 & 0.00 & 0.22 \\
\hline $\mathrm{EE}, \mathrm{g} / 100 \mathrm{~g} \mathrm{DM}$ & $4.34^{d}$ & $4.19^{d}$ & $4.58^{\mathrm{cd}}$ & $4.69^{c d}$ & $4.39^{d}$ & $4.33^{d}$ & $5.03^{b c}$ & $5.57^{\mathrm{ab}}$ & $4.57^{\mathrm{cd}}$ & $4.26^{d}$ & $5.34^{\mathrm{ab}}$ & $5.70^{\mathrm{a}}$ & 0.096 & 0.00 & 0.00 & 0.11 \\
\hline CF, g /100 g DM & 23.86 & 24.05 & 22.86 & 23.74 & 23.67 & 23.75 & 23.47 & 23.66 & 22.64 & 23.68 & 24.42 & 23.38 & 0.134 & 0.93 & 0.71 & 0.15 \\
\hline ADF, $g / 100 \mathrm{~g} \mathrm{DM}$ & $26.94^{\mathrm{cd}}$ & $26.41^{d}$ & $30.51^{\mathrm{ab}}$ & $27.85^{\mathrm{cd}}$ & $26.91^{\mathrm{cd}}$ & $26.84^{\mathrm{cd}}$ & $29.41^{a b c}$ & $27.89^{\mathrm{cd}}$ & $27.99^{\mathrm{cd}}$ & $28.61^{\text {bcd }}$ & $29.32^{\mathrm{abc}}$ & $31.74^{\mathrm{a}}$ & 0.321 & 0.01 & 0.00 & 0.08 \\
\hline NDF, g /100 g DM & $65.25^{\mathrm{a}}$ & $61.16^{\mathrm{ab}}$ & $62.85^{\mathrm{ab}}$ & $64.32^{\mathrm{a}}$ & $58.68^{b}$ & $58.11^{\mathrm{b}}$ & $64.87^{\mathrm{a}}$ & $62.51^{\mathrm{ab}}$ & $61.11^{\mathrm{ab}}$ & $58.05^{\mathrm{b}}$ & $62.52^{\mathrm{ab}}$ & $58.98^{b}$ & 0.556 & 0.02 & 0.15 & 0.15 \\
\hline ADL, g /100 g DM & $3.07^{\mathrm{cd}}$ & $2.36^{d}$ & $7.65^{\mathrm{a}}$ & $4.11^{\mathrm{bcd}}$ & $3.24^{\mathrm{cd}}$ & $3.08^{\mathrm{cd}}$ & $5.94^{\mathrm{ab}}$ & $4.22^{\mathrm{bcd}}$ & $5.35^{\mathrm{abc}}$ & $4.93^{\mathrm{bcd}}$ & $4.90^{\mathrm{bcd}}$ & $6.68^{\mathrm{ab}}$ & 0.319 & 0.05 & 0.00 & 0.03 \\
\hline Ash, g /100 g DM & $5.35^{\mathrm{ab}}$ & $5.64^{\mathrm{a}}$ & $5.47^{\mathrm{ab}}$ & $5.34^{\mathrm{ab}}$ & $5.21^{\mathrm{ab}}$ & $5.20^{\mathrm{ab}}$ & $5.21^{\mathrm{ab}}$ & $5.15^{\mathrm{b}}$ & $5.35^{\mathrm{ab}}$ & $5.17^{\mathrm{b}}$ & $5.30^{\mathrm{ab}}$ & $5.21^{\mathrm{ab}}$ & 0.040 & 0.04 & 0.78 & 0.77 \\
\hline NFE, g /100 g DM & $60.90^{\mathrm{abcd}}$ & $60.26^{\mathrm{abcd}}$ & $61.42^{\mathrm{ab}}$ & $60.43^{\mathrm{abcd}}$ & $61.15^{\mathrm{abc}}$ & $61.03^{\mathrm{abc}}$ & $60.29^{\mathrm{abcd}}$ & $59.52^{\mathrm{cd}}$ & $61.88^{a}$ & $61.15^{\mathrm{abc}}$ & $59.2^{d}$ & $59.89^{\mathrm{bcd}}$ & 0.180 & 0.77 & 0.02 & 0.09 \\
\hline Fleig score ${ }^{1}$ & $90.81^{\mathrm{ab}}$ & $92.35^{\mathrm{ab}}$ & $85.13^{b c}$ & $63.52^{\mathrm{e}}$ & $98.33^{a}$ & $94.63^{\mathrm{ab}}$ & $77.28^{\mathrm{cd}}$ & $63.36^{\mathrm{e}}$ & $95.79^{\mathrm{ab}}$ & $99.98^{\mathrm{a}}$ & $79.39^{\text {cd }}$ & $69.22^{\mathrm{de}}$ & 2.313 & 0.39 & 0.00 & 0.30 \\
\hline ME, Mcal/kg DM & $2.43^{b c}$ & $2.42^{c}$ & $2.48^{\mathrm{ab}}$ & $2.45^{\mathrm{abc}}$ & $2.44^{\mathrm{abc}}$ & $2.44^{\mathrm{bc}}$ & $2.48^{\mathrm{abc}}$ & $2.49^{\mathrm{ab}}$ & $2.49^{\mathrm{ab}}$ & $2.44^{\mathrm{bc}}$ & $2.44^{\mathrm{abc}}$ & $2.50^{\mathrm{a}}$ & 6.431 & 0.18 & 0.02 & 0.18 \\
\hline
\end{tabular}

a-e Within rows, means with a common superscript are not significantly different at $P \leq 0.05$

T10: silage sprayed with $10 \mathrm{ml}$ oregano essential oil per $75 \mathrm{~cm}^{2}$ opened silage surface; T20: silage sprayed with $20 \mathrm{ml}$ oregano essential oil per $75 \mathrm{~cm}{ }^{2}$ opened silage surface; WSC: water-soluble carbohydrate; DM: dry matter; OM: organic matter; CP: crude protein; EE: ether extract; NFE: nitrogen free extract; CF: crude fibre; ADF: acid detergent fibre; NDF: neutral detergent fibre; ADL: acid detergent lignin; ME: metabolizable energy

${ }^{1}$ Fleig scores between 80 and 100 are considered indicative of very good quality silage; 61 to 80 are good; 41 to 60 are medium; 21 to 40 are low quality; between 0 and 20 are considered indicative of poor-quality silage 
Spraying OEO onto silages did not affect the calculated ME content of the silages. However, the predicted ME contents of all silages increased significantly with time (Table 4).

\section{Conclusions}

Treatment of BPS with OEO protected the quality of these silages for up to 168 hours, probably as a result of suppressing microbial activity. Spraying $10 \mathrm{ml}$ OEO on the $75 \mathrm{~cm}^{2}$ surface area after opening SBPSs decreased LAB, TLB, yeast and mould growth in silages up to 120 hours without affecting the nutrient contents. Thus, OEO may be used on farms as a treatment for BPS silage, if its cost is balanced against the losses incurred in silages because of mould and spoilage. Further studies can be conducted to eliminate its side effects on desirable microbiota.

\section{Acknowledgements}

The authors would like to thank Department of Agricultural Biotechnology, Faculty of Agriculture, Erciyes University Research Assistant Mr Olgay Kaan Tekin, Kırşehir Ahi Evran Üniversity, Faculty of Agriculture, Department of Agricultural Biotechnology students Mrs Dicle Çiçek and Mrs Burçin Durmuş and Mrs Zeynep Kar and Mr Ruhat Furkan Acar for their contributions to laboratory work. This study was supported by Kırşehir Ahi Evran University Office of Coordinatorship of Scientific Research Projects with PYO-ZRT.4001.15.001 registration number.

\section{Authors' Contributions}

$\mathrm{HÇ}$ and GF contributed to the project idea, design and execution of the study. HÇ, AGF, IC and HÇ was in charge of laboratory analyses. IC performed statistical analyses. AŞ was responsible for supervision and writing the manuscript.

\section{Conflict of Interest Declaration}

The authors declare that there is no conflict of interests regarding the publication of this manuscript.

\section{References}

Aldemir, R., Bingol, N., Karsli, M. \& Dede, S., 2019. Effect of substituting barley grain with wet sugar beet pulp silage on some blood metabolites in lambs. Indian J. Anim. Res. 53(1), 55-58. https://arccjournals.com/journal/indian-journal-of-animal-research/B-861

AOAC, 1998. Official methods of analysis. 16th edition. 4th revision. Washington, DC.

Borreani, G., Tabacco, E., Schmidt, R.J., Holmes, B.J. \& Muck, R.E., 2018. Silage review: Factors affecting dry matter and quality losses in silages. J. Dairy Sci. 101, 3952-3979. http://dx.doi.org/10.3168/jds.2017-13837

Çayıroğlu, H., Coşkun, İ. \& Şahin, A., 2016. Factors affecting the aerobic stability of silage and improvement strategies. Alinteri J. Agric. Sci. 31(2), 91-97. Doi: https://dx.doi.org/10.28955/alinterizbd.285159

Çelebi, A., 2010. Mikrobiyal inokulantlar ve hücre duvarını parçalayıcı enzimlerinin yonca silajında fermantasyon özellikleri ve aerobik stabilite üzerine etkileri. MSc Thesis, 283207 Namik Kemal University, Graduate School of Natural and Applied Sciences. http://hdl.handle.net/20.500.11776/698 Accessed 11 March 2019

Chaves, A., Baah, J., Wang, Y., McAllister, T. \& Benchaar, C., 2012. Effects of cinnamon leaf, oregano and sweet orange essential oils on fermentation and aerobic stability of barley silage. J. Sci. Food Agric. 92(4), 906-915. Doi: https://doi.org/10.1002/jsfa.4669

Ferrero, F., Piano, S., Tabacco, E. \& Borreani, G., 2019. Effects of conservation period and Lactobacillus hilgardii inoculum on the fermentation profile and aerobic stability of whole corn and sorghum silages. J. Sci. Food Agric. 99(5), 2530-2540. Doi: https://doi.org/10.1002/jsfa.9463

Filya, I., 2004. Nutritive value and aerobic stability of whole crop maize silage harvested at four stages of maturity. Anim. Feed Sci. Technol. 116(1-2), 141-150. Doi: https://doi.org/10.1016/j.anifeedsci.2004.06.003

Filya, I., Sucu, E. \& Canbolat, O., 2004. Researches on using organic acids in the silage fermentation. J. Agric. Faculty Bursa Uludag University 18(2), 35-45.

Gerlach, K., Reimink, A., Messerschmidt, U. \& Südekum, K., 2017. Ensiled sugar beets as dietary component and their effect on preference and dry matter intake by goats. Arch. Anim. Nutr. 71(4), 297-310. Doi: https://doi.org/10.1080/1745039X.2017.1322795

Hellwing, A., Messerschmidt, U., Larsen, M. \& Weisbjerg, M., 2017. Effects of feeding sugar beets, ensiled with or without an additive, on the performance of dairy cows. Livest. Sci. 206, 37-44. Doi: http://dx.doi.org/10.1016/j.livsci.2017.10.007

Kaya, Ș., 2017. Practical guide for some aerobic spoilage in silage. Mustafa Kemal University J. Agric. Faculty, 22(1), 127-134.

Kılıç, A., 1986. Silo feed (teaching, learning, and practice recommendation) (In Turkish): Silo yemi el kitabı (öğretim, öğrenim ve uygulama önerileri). bilgehan Basım Evi, Bornova-İzmir.

Kızılşimsek, M., Erol, A., Ertekin, I., Dönmez, R. \& Katrancı, B., 2016. Relationship among silage micro flora and their effects on silage fermentation and quality. University of Kahramanmaraş Sutcu Imam, J. Natural Sci. 19(2), 136140.

Koç, F., Coșkuntuna, L., Özdüven, M. \& Coșkuntuna, A., 2010. The effect of organic acid usage at various temperatures on fermentation and aerobic stability of vetch-grain silages. J. Tekirdag Agric. Faculty 7(2), 159-165.

Konca, Y., Alçiçek, A. \& Yaylak, E., 2005. Determination of quality of the silage made in dairy cattle farms. J. Anim. Prod. 46, 6-13. http://dergipark.gov.tr/hayuretim/issue/7622/99863 
Kung, L., 2001. Silage fermentation and additives. Direct-fed microbial, enzyme \& forage additive compendium, Miller, Minnetonka, MN.

Kung, Jr, L., Shaver, R., Grant, R. \& Schmidt, R., 2018. Silage review: Interpretation of chemical, microbial, and organoleptic components of silages. J. Dairy Sci. 101, 4020-4033. https://doi.org/10.3168/jds.2017-13909

Muck, R., Nadeau, E., McAllister, T., Contreras-Govea, F., Santos, M. \& Kung Jr, L., 2018. Silage review: Recent advances and future uses of silage additives. J. Dairy Sci. 101, 3980-4000. https://doi.org/10.3168/jds.201713839

Mutavhatsindi, T.F., Nkosi, B.D., Baloyi, J.J. \& Langa, T., 2018. Effects of a fibrolytic enzyme and bacterial inoculants on the fermentation, chemical composition and aerobic stability of ensiled potato hash. S. Afr. J. Anim. Sci. 48(2), 244-252. Doi: http://dx.doi.org/10.4314/sajas.v48i2.5

Naderi, N., Ghorbani, G., Sadeghi-Sefidmazgi, A., Nasrollahi, S. \& Beauchemin, K., 2016. Shredded beet pulp substituted for corn silage in diets fed to dairy cows under ambient heat stress: Feed intake, total-tract digestibility, plasma metabolites, and milk production. J. Dairy Sci. 99(11), 8847-8857. Doi: https://doi.org/10.3168/jds.2016-11029

Özelçam, H. \& Dașıkan, H., 2017. Effect of carvacrol adding to corn silage on the aerobic stability. Journal of Agriculture Faculty of Ege University, 54(4), 409-412. https://dx.doi.org/10.20289/zfdergi.386442

Sargın, H. \& Denek, N., 2017. Effect of adding different levels of dried molasses sugar beet pulp on the silage quality and in vitro digestibility of wet tomato pomace silage. Harran University Journal of The Faculty of Veterinary Medicine, 6, 84-89. Doi: https://doi.org/10.31196/huvfd.325772 (In Turkish)

Silva, L.D., Pereira, O.G., Silva, T.C., Leandro, E.S., Paula, R.A., Santos, S.A., Ribeiro, K.G. \& Valadares Filho, S.C., 2018. Effects of Lactobacillus buchneri isolated from tropical maize silage on fermentation and aerobic stability of maize and sugarcane silages. Grass and Forage Science 73(3), 660-670. Doi: https://doi.org/10.1111/gfs.12360

Soycan Önenç, S., Coşkuntuna, L., Koç, F., Özdüven, M. \& Gümüş, T., 2017. Effects of essential oils of oregano and cinnamon on fermentation quality and in vitro metabolic energy of field pea silages. Journal of Animal Production 58(2), 39-44. Doi: https://doi.org/10.29185/hayuretim.331326 (In Turkish)

Soycan Önenç, S., Koç, F., Coşkuntuna, L., Özdüven, M. \& Gümüş, T., 2015. The effect of oregano and cinnamon essential oils on fermentation quality and aerobic stability of field pea silages. Asian-australas. J. Anim. Sci., 28(9), 1281. Doi: https://doi.org/10.5713/ajas.15.0122

Toruk, F., Koç, F. \& Gönülol, E., 2010. Color changes of package silage in period of aerobic stability. Journal of Tekirdag Agricultural Faculty, 7(1), 23-30. http://hdl.handle.net/20.500.11776/1514 (In Turkish)

TSE, 1991. Metabolic energy determination of animal feeds (chemical method), TSE 9610. In Turkish: Hayvan Yemleri Metabolik (Çevrilebilir) Enerji Tayini (Kimyasal Metod). Turkish Standards Institution, Ankara.

Turan, A. \& Önenç Soycan, S., 2018. Effect of cumin essential oil usage on fermentation quality, aerobic stability and in vitro digetibility of alfalfa silage. Asian-Australas. J. Anim. Sci., 31(8), 1252. https://dx.doi.org/10.5713\%2Fajas.17.0834

Ülger, I., Kaliber, M., Ayaşan, T., Küçük, O., 2018. Chemical composition, organic matter digestibility and energy content of apple pomace silage and its combination with corn plant, sugar beet pulp and pumpkin pulp. S. Afr. J. Anim. Sci. 48(3), 497-503. http://dx.doi.org/10.4314/sajas.v48i3.10

Van Soest, P., Robertson, J. \& Lewis, B., 1991. Methods for dietary fibre, neutral detergent fibre and non-starch polysaccharides in relation to animal nutrition. J. Dairy Sci. 74, 3583-3597.

Zheng, Y., Lee, C., Yu, C., Cheng, Y., Zhang, R., Jenkins, B. \& VanderGheynst, J., 2013. Dilute acid pretreatment and fermentation of sugar beet pulp to ethanol. Appl. Energy. 105, 1-7. Doi: http://dx.doi.org/10.1016/j.apenergy.2012.11.070

Zheng, Y., Yu, C., Cheng, Y. S., Zhang, R., Jenkins, B. \& VanderGheynst, J. S. 2011. Effects of ensilage on storage and enzymatic degradability of sugar beet pulp. Bioresource Technology 102(2), 1489-1495. https://doi.org/10.1016/j.biortech.2010.09.105 